\title{
Prenylated Flavonoids from the Stems and Roots of Tripterygium wilfordii
}

Yang Chen ${ }^{\mathrm{a}}$, Jianping Zhao ${ }^{\mathrm{b}}$, Yixing Qiu ${ }^{\mathrm{a}}$, Hanwen Yuanª Shabana I. Khan ${ }^{\mathrm{b}}$, Nusrat Hussain ${ }^{\mathrm{a}, \mathrm{c}}$, M. Iqbal Choudhary ${ }^{\mathrm{c}}$, Feng Zeng ${ }^{\mathrm{d}}$, De-An Guo ${ }^{\mathrm{d}}$, Ikhlas A. Khan ${ }^{\mathrm{b}}$, Wei Wang ${ }^{\mathrm{a}, *}$

${ }^{a} T C M$ and Ethnomedicine Innovation \& Development Laboratory, Sino-Pakistan TCM and Ethnomedicine Research Center, School of Pharmacy, Hunan University of Chinese Medicine, Changsha, 410208, P.R. China.

${ }^{\mathrm{b}}$ National Center for Natural Products Research, Research Institute of Pharmaceutical Sciences, University of Mississippi, University, MS 38677, United States.

${ }^{\mathrm{c}}$ H.E.J. Research Institute of Chemistry, International Center for Chemical and Biological Sciences, University of Karachi, Karachi, Pakistan. 75270.

${ }^{\mathrm{d} S h a n g h a i}$ Research Center for Modernization of Traditional Chinese Medicine, National Engineering Laboratory for TCM Standardization Technology, Shanghai Medica, CAS, Shanghai 201203, China.

*Corresponding Author : Wei Wang Tel.: +86 1365743 8606; fax: +86 7318845 8227; E-mail: wangwei402@hotmail.com. 
ABSTRACT: Phytochemical investigation on the stems and roots of Tripterygium wilfordii led to the isolation and characterization of three new prenylated flavanones, tripteryols A-C (1-3), along with ( \pm )-5,4'-dihydroxy-2'-methoxy-6',6"-dimethypyraro-(2",3":7,8)-6-methyflavanone (4), and ((2S)-5,7,4'-trihydroxy-2'-methoxy-8,5'-di(3-methyl-2-butenyl)-6-methylflavanone Structures of the compounds 1-5 were elucidated using spectroscopic techniques, such as UV, IR, NMR (1D and 2D), and HRESI-MS. Tripteryols B (2) was found active in the antimicrobial assay against Cryptococcus neoformans, Pseudomonas aeruginosa, vancomycin-resistant Enterococcus faecalis (VRE) and methicillin-resistant Staphylococcus aureus (MRSA) with IC50 values in the range of 2.95-8.59 $\mu \mathrm{g} / \mathrm{mL}$. Compounds $\mathbf{4}$ and $\mathbf{5}$ showed significant antimicrobial activities against C. neoformans, MRSA and Staphylococcus aureus with IC50 values in the range of 1.06-2.60 $\mu \mathrm{g} / \mathrm{mL}$. Additionally, significant antimalarial activities of tripteryols A-B (1-2) against chloroquine-sensitive D6 and resistant W2 clones of Plasmodium falciparum were observed and none of the compounds 1-5 were cytotoxic to Vero cells.

Key words: Tripterygium wilfordii; Celastraceae; Flavanone; Antimicrobial; Antimalarial; NMR. 


\section{Introduction}

The stems and roots of $T$. wilfordii are named Lei-gong-teng in Chinese, and have been used as Chinese herbal medicine for hundreds of years. It is mainly distributed in regions of Eastern and Southern China, Korea, and Japan [1-2]. A variety of preparations of T. wilfordii, such as “Tripterygium glycosides tablet”, and “Tripterygium-loaded solid lipid nanoparticles”, have been widely used to treat auto-immune and inflammatory diseases [3-5]. Previous phytochemical investigations revealed sesquiterpenoid alkaloids, diterpenoids and triterpenes as main chemical constituents of T. wilfordii [6-7]. However, limited study focused on the isolation of flavonoids from $T$. wilfordii, except for one of our previous phytochemical investigations on the plant, which reported two prenylated and C-methylated flavanones with moderate antiproliferative activity [8].

In our ongoing phytochemical investigation on T. wilfordii, three new prenylated flavanones, tripteryols A-C (1-3), along with two known flavanones ( \pm )-5,4'-dihydroxy-2'-methoxy-6',6"dimethypyraro-(2",3":7,8)-6-methyflavanone (4), and ((2S)-5,7,4'-trihydroxy-2'-methoxy-8,5'di(3-methyl-2-butenyl)-6-methylflavanone (5) were isolated and characterized from ethanol extract of the stems and roots. Compounds 1-5 were tested for their antimicrobial, antimalarial, and cytotoxicity activities. Tripteryol B (2) showed good antimicrobial activity, while 4 and 5 were significantly active in the antimicrobial assay. Tripteryols A-B (1-2) also showed significant antimalarial activities, while 1-5 were found inactive in the cytotoxicity assay.

\section{Experimental}

\subsection{General experimental procedures}

Optical rotations were determined on a Rudolph Research Analytical Autopol IV automatic polarimeter. UV spectra were measured in methanol on a Varian Cary 50 Bio UV-visible 
spectrophotometer. IR spectra were recorded on an Agilent Technologies Cary 630 FTIR spectrometer. NMR spectra were recorded on a Bruker DRX-500 spectrometers with TMS as the internal standard. HRESI-MS data was obtained on an Agilent Technologies 6200 series mass spectrometer or Waters Xevo G2-XS Q TOF mass spectrometer. Preparative HPLC, Agilent Series 1200 system consisting of a quaternary delivery system, an auto-sampler with a diode array detector and a semi-preparative column Eclipse XDB-C18 column $(250 \mathrm{~mm} \times 9.4 \mathrm{~mm}, 5 \mu \mathrm{m})$ was used for compounds purification.

\subsection{Plant material}

Debarked stems and roots of Tripterygium wilfordii were collected from Tian Heng drugstore, Beijing, China. The plant material was identified by Prof. De-an Guo. A voucher specimen No. 20080220 was deposited at TCM and Ethnomedicine Innovation \& Development Laboratory, Hunan University of Chinese Medicine.

\subsection{Extraction and isolation}

Air-dried debarked stems and roots of $T$. wilfordii $(9.5 \mathrm{~kg}$ ) were extracted by refluxing with $95 \%$ ethanol for $2 \mathrm{~h}$. The pooled extract was concentrated under vacuum to yield a crude extract (380 g). The crude extract (380 g) was suspended in water (1 L) and partitioned successively with petroleum ether (PE) and ethyl acetate (EtOAc) to afford $20 \mathrm{~g}$ and $135 \mathrm{~g}$ fractions, respectively. The ethyl acetate soluble part was subjected to column chromatography (CC) over silica gel $(100 \times 10 \mathrm{~cm})$ with gradient $\mathrm{CHCl}_{3} / \mathrm{MeOH}(100: 0-50: 50)$ to obtain 9 fractions (Fr. 1Fr. 9). Fr. 2 (50 g) was applied to CC over silica gel using PE/Acetone gradients (5:0-5:2) to obtain 9 subfractions (Fr. 2A-Fr. 2I). Fr. 2C was further purified over Sephadex LH-20 (methanol as mobile phase), followed by semipreparative HPLC to obtain 2 (10.6 mg) and $\mathbf{1}$ (4.3 mg). Fr. 2F was subjected to Sephadex LH-20 column using methanol as solvent, followed by 
semipreparative HPLC using 85\% $\mathrm{MeOH}-\mathrm{H}_{2} \mathrm{O}$ solvent system to yield 3 (3.5 mg). Compounds 4 (6.8 mg) and 5 (7.2 mg) were obtained from Fr. 2E by Sephadex LH-20 column, using methanol as solvent.

2.3.1 Tripteryol A (1): obtained as white amorphous powder; $[\alpha]_{D}^{25}-9.4$ (c 1.1, MeOH); UV (MeOH) $\lambda_{\max }(\log \varepsilon) 294$ (3.99) nm; IR (KBr) $v_{\max }$ 3401, 2926, 1627, 1450, 1371, 1295, 1191, 1127 and $1020 \mathrm{~cm}^{-1}$; ${ }^{1} \mathrm{H}$ NMR (Pyridine- $d_{5}, 500 \mathrm{MHz}$ ) and ${ }^{13} \mathrm{C}$ NMR (Pyridine- $d_{5}, 125 \mathrm{MHz}$ ), see Table 1; Negative HRESI-MS m/z 449.1967 [M-H] ${ }^{-}$(calcd for $\mathrm{C}_{27} \mathrm{H}_{29} \mathrm{O}_{6}, 449.1964$ ).

2.3.2 Tripteryol B (2): obtained as yellowish amorphous powder; $[\alpha]_{D}^{25} 0$ (c 1.75, MeOH); UV (MeOH) $\lambda_{\max }(\log \varepsilon) 291$ (3.82) nm; IR (KBr) $v_{\max }$ 3364, 2920, 2361, 1630, 1508, 1442, 1379, 1298, 1168, 1079 and $1017 \mathrm{~cm}^{-1}$; ${ }^{1} \mathrm{H}$ NMR (CD $3 \mathrm{OD}, 500 \mathrm{MHz}$ ) and ${ }^{13} \mathrm{C}$ NMR (CD $\mathrm{OD}, 125$ MHz), see Table 1; Negative HRESI-MS m/z 437.1984 [M-H]' (calcd for $\mathrm{C}_{26} \mathrm{H}_{29} \mathrm{O} 6$, 437.1964).

2.3.3 Tripteryol $C$ (3): obtained as yellow amorphous powder; $[\alpha]_{D}^{25}-115.6$ (c 1.09, MeOH); UV $(\mathrm{MeOH}) \lambda_{\max }(\log \varepsilon) 292(4.04) \mathrm{nm}$; IR (KBr) $v_{\max }$ 3382, 2925, 2360, 1633, 1473, 1435, 1382, 1299, 1161, 1096 and $1011 \mathrm{~cm}^{-1} ;{ }^{1} \mathrm{H}$ NMR (Pyridine- $d_{5}, 500 \mathrm{MHz}$ ) and ${ }^{13} \mathrm{C}$ NMR (Pyridine- $d 5$, $125 \mathrm{MHz}$ ), see Table 1; Negative HRESI-MS m/z $393.1316[\mathrm{M}-\mathrm{H}]^{-}$(calcd for $\mathrm{C}_{23} \mathrm{H}_{21} \mathrm{O}_{6}$, 393.1338).

\subsection{Antimalarial bioassay}

The in vitro antimalarial activities of tripteryol A-C (1-3) were determined against chloroquine-sensitive (D6) and resistant (W2) clones of Plasmodium falciparum, which based on the determination of the parasitic lactate dehydrogenase (pLDH) activity using Malstat reagent, utilizing an assay described previously [9]. IC50 values were computed from the dose response curves. Artemisinin (Aldrich-Sigma, St. Louis, MO) was used as positive control. DMSO was used as a vehicle control. 


\subsection{Antimicrobial bioassay}

Microorganisms, Cryptococcus neoformans ATCC 90113, Pseudomonas aeruginosa ATCC 27853, Low-level vancomycin-resistant Enterococcus faecalis ATCC 51299, methicillinresistant Staphylococcus aureus ATCC 43300 (MRSA), and Staphylococcus aureus ATCC 29213 were obtained from American Type Culture Collection (Manassa, VA). Susceptibility testing were done using modified versions of the NCCLS methods [10-12]. Briefly, Samples (dissolved in DMSO) were serially diluted in saline, and transferred in duplicates to 96-well flat bottom microplates. Microbial inocula were prepared by correcting the OD630 of microbe suspensions in incubation broth to afford recommended inocula [9]. Amphotericicin B, ciprofloxacin, and vancomycin (ICN Biomedicals, Ohio) were used as positive control drugs in each assay.

\subsection{Cytotoxicity}

Compounds 1-5 were also tested for their in vitro cytotoxicities against mammalian kidney fibroblasts (VERO) cells. The assay was performed in 96-well tissue culture-treated microplates as described earlier [13]. In brief, cells were seeded to the wells of the plate at a density of 25,000 cells/well and incubated for $24 \mathrm{~h}$ at $37^{\circ} \mathrm{C}$. Follwing $48 \mathrm{~h}$ of incubation with samples, the number of viable cells were determined using Neutral Red procedure.

\section{Results and discussion}

The ethyl acetate soluble part from ethanol extract of $T$. wilfordii was successively chromatographed over silica gel, Sephadex LH-20, and semi-preparative reverse-phase HPLC to obtain three new prenylated flavanones, tripteryol A-C (1-3).

Tripteryol A (1) was obtained as white powder. Its molecular formula was determined as $\mathrm{C}_{27} \mathrm{H}_{30} \mathrm{O}_{6}$ by psuedomolecular ion peak $[\mathrm{M}-\mathrm{H}]^{-}$in HRESI-MS at $\mathrm{m} / \mathrm{z} 449.1967$ (calcd. for 
449.1964), indicating 13 degrees of unsaturation. IR spectrum showed absorptions for hydroxyl and carbonyl groups at 3401 and $1627 \mathrm{~cm}^{-1}$, respectively. ${ }^{1} \mathrm{H}$ NMR spectrum (Table 1) of $\mathbf{1}$ displayed one hydroxyl group [ $\left.\delta_{\mathrm{H}} 13.10(1 \mathrm{H}, \mathrm{s}, 5-\mathrm{OH})\right]$, two singlet aromatic protons $\left[\delta_{\mathrm{H}} 6.64\right.$ $\left(1 \mathrm{H}, \mathrm{s}, \mathrm{H}-3^{\prime}\right)$ and $\delta_{\mathrm{H}} 7.50\left(1 \mathrm{H}, \mathrm{s}, \mathrm{H}-6^{\prime}\right)$ ], a methoxy group [ $\left.\delta_{\mathrm{H}} 3.71\left(3 \mathrm{H}, \mathrm{s}, 2^{\prime}-\mathrm{OCH}_{3}\right)\right]$, an isoprenyl group $\left[\delta_{\mathrm{H}} 3.65\left(2 \mathrm{H}, \mathrm{m}, \mathrm{H}-1^{\prime \prime}\right), \delta_{\mathrm{H}} 5.60\left(1 \mathrm{H}, \mathrm{m}, \mathrm{H}-2^{\prime \prime}\right), \delta_{\mathrm{H}} 1.76\left(3 \mathrm{H}, \mathrm{s}, \mathrm{H}-4^{\prime \prime}\right)\right.$ and $\delta_{\mathrm{H}} 1.68(3 \mathrm{H}, \mathrm{s}, \mathrm{H}-$ $\left.\left.5^{\prime \prime}\right)\right]$, a 2,2-dimethylpyran ring unit $\left[\delta_{\mathrm{H}} 1.46(6 \mathrm{H}, \mathrm{d})\right.$, the two doublets at $\delta_{\mathrm{H}} 5.58(\mathrm{~d}, J=9.7 \mathrm{~Hz}$, $\left.\mathrm{H}-2^{\prime \prime \prime}\right)$ and $\left.6.49\left(\mathrm{~d}, J=9.7 \mathrm{~Hz}, \mathrm{H}-1^{\prime \prime \prime}\right)\right]$ and a C-methyl group $[\delta \mathrm{H} 2.45(3 \mathrm{H}, \mathrm{s})] .{ }^{13} \mathrm{C}$ NMR spectrum (Table 1) of $\mathbf{1}$ suggested a flavanone skeleton [8]. The heteronuclear multiple quantum correlations (HMQC) and heteronuclear multiple bond correlations (HMBC) were used to determine connections of substituents (Fig. 2). The HMBC of H-1"'/C-4' and C-3"', H-2"'/C-5', H-6'/C-2, C-2', C-4' and C-1'", H-3'/C-1' and C-5' revealed that dimethylpyran group should be fused to C-4' and C-5' of ring B. A C-methyl group [ $\left.\delta_{\mathrm{H}} 2.45(3 \mathrm{H}, \mathrm{s}), \delta_{\mathrm{C}} 9.1\right]$ at C-6 and two hydroxy group attached to C-5 and C-7 respectively were determined by HMBC cross-peaks of a methyl ( $\left.\delta_{\mathrm{H}} 2.45\right)$ with C-7 and C-5, and HMBC of $\delta_{\mathrm{H}} 13.10$ to C-5, C-6 and C-4a. A methoxy group at $\mathrm{C}-2$ ' was identified by $\mathrm{HMBC}$ of $\mathrm{H}_{3}-\mathrm{MeO} / \mathrm{C}-2$ '. The absolute configuration was determined as "S" for the chiral center at C-2 based on the negative optical rotation value [14]. Therefore, 1 was assigned as (2S)-5,7-dihydroxy-2'-methoxy-8-(3-methyl-2-butenyl)-4',5'-(3,3dimethylpyrano)-6-methylflavanone.

Tripteryol B (2) was obtained as yellowish powder. HRESI-MS at m/z $437.1984[\mathrm{M}-\mathrm{H}]^{-}$ (calcd. for 437.1964), demonstrated the molecular formula of 2 to be $\mathrm{C}_{26} \mathrm{H}_{30} \mathrm{O}_{6}$. The IR spectrum showed presence of hydroxyl $\left(3363 \mathrm{~cm}^{-1}\right)$ and carbonyl groups $\left(1630 \mathrm{~cm}^{-1}\right)$. The ${ }^{1} \mathrm{H}$ and ${ }^{13} \mathrm{C}$ NMR spectra (Table 1) indicated that $\mathbf{2}$ was also a flavanone. The resonances for two isoprenyl groups were observed at $\delta_{\mathrm{H}} 3.21\left(2 \mathrm{H}, \mathrm{m}, \mathrm{H}-1^{\prime \prime}\right), \delta_{\mathrm{H}} 3.26\left(2 \mathrm{H}, \mathrm{d}, \mathrm{H}-1^{\prime \prime \prime}\right), \delta_{\mathrm{H}} 5.19\left(1 \mathrm{H}, \mathrm{m}, \mathrm{H}-2^{\prime \prime}\right), \delta_{\mathrm{H}}$ 
$5.31\left(1 \mathrm{H}, \mathrm{m}, \mathrm{H}-2{ }^{\prime \prime \prime}\right)$, and $\delta_{\mathrm{H}} 1.64,1.63,1.74,1.71$ (4Me, s). The locations of the substituents were further determined by HMBCs, in which correlations of H-1"/C-7 and C-8a, H-6/C-4a and C-8, H-6'/C-2 and C-1'", H-3'/C-1' and C-5', H-1'"'/C-4' and C-6' revealed that two isoprenyl groups should be attached at C-8 and C-5' respectively. The three single aromatic protons were assigned to $\mathrm{H}-6, \mathrm{H}-6^{\prime}$ and $\mathrm{H}-3^{\prime}$. The assignments of $\mathrm{OH}-5, \mathrm{MeO}-2^{\prime}$ and $\mathrm{OH}-4$ ' were confirmed by the HMBC (Fig. 2). The optical rotation was found zero, which implied it should be a racemate [8, 15]. Based on the above evidence, 2 was established as ( \pm ) -5,7,4'-trihydroxy-2'-methoxy-8,5'di(3-methyl-2-butenyl)-flavanone.

Tripteryol C (3) was obtained as yellow powder. Its molecular formula was determined as $\mathrm{C}_{23} \mathrm{H}_{22} \mathrm{O}_{6}$ by psuedomolecular ion peak [M-H] in HRESI-MS at $\mathrm{m} / \mathrm{z} 393.1316$ (calcd. for 393.1338). Similar to 1 , its characteristic IR ( $v_{\max } 3381,1633$ and $\left.1473 \mathrm{~cm}^{-1}\right),{ }^{1} \mathrm{H}$ and ${ }^{13} \mathrm{C}$ NMR data suggested a flavanone basic skeleton [8]. Furthermore, the ${ }^{1} \mathrm{H}$ NMR spectrum showed a hydroxyl group [ $\left.\delta_{\mathrm{H}} 12.86(1 \mathrm{H}, \mathrm{s}, \mathrm{OH}-5)\right]$, three aromatic protons [ $\delta_{\mathrm{H}} 8.07(1 \mathrm{H}, \mathrm{s}, \mathrm{H}-6$ ') $) 7.85(1 \mathrm{H}$, s, H-3'), 6.55 (1H, s, H-6)] and a isoprenyl group [ $\delta_{\mathrm{H}} 3.70$ (2H, m, H-1"), $5.71\left(1 \mathrm{H}, \mathrm{t}, \mathrm{H}-2^{\prime \prime}\right), 1.80$ (3H, s, H-4"), $\left.1.71\left(3 \mathrm{H}, \mathrm{s}, \mathrm{H}-5^{\prime \prime}\right)\right]$. The isoprenyl group was located at C-8 according to the HMBC of H-1"/C-7, C-8 and C-8a. A pair of olefinic protons at $\delta_{\mathrm{H}} 6.91\left(1 \mathrm{H}, \mathrm{d}, J=2.1 \mathrm{~Hz}, \mathrm{H}-1^{\prime \prime}\right)$ and $\delta_{\mathrm{H}} 7.85\left(1 \mathrm{H}, \mathrm{d}, J=2.1 \mathrm{~Hz}, \mathrm{H}-2^{\prime \prime \prime}\right)$ were located at $\delta_{\mathrm{C}} 107.6\left(\mathrm{C}-1^{\prime \prime \prime}\right)$ and $145.7\left(\mathrm{C}-2^{\prime \prime \prime}\right)$, respectively, suggesting a benzofuran moiety in the structure of $\mathbf{3}$. The locations of the furan ring, OH-7, OH-5, and MeO-2' were confirmed by HMBCs (Fig. 2). The (2S) absolute configuration was assigned according to its negative optical activity. Therefore, 3 was identified as (2S)-5,7dihydroxy-2'-methoxy-8-(3-methyl-2-butenyl)-4',5'-furone-flavanone.

The two known flavanones were identified as ( \pm )-5,4'-dihydroxy-2'-methoxy-6',6"dimethypyraro-(2",3":7,8)-6-methyflavanone (4) and ((2S)-5,7,4'-trihydroxy-2'-methoxy-8,5'- 
di(3-methyl-2-butenyl)-6-methylflavanone (5), based on the spectroscopic analyses, and comparison with literature data [8].

To best of our knowledge there are many reports of C-methylated flavonoids [16-18], while B ring furanized flavanones are rare in nature. Tripteryol C (3) (the furanized flavanone) was found as $O$-methylated derivative of cudraflavanone E. Chen et al., proposed a biogenetic pathway for cudraflavanone E, suggesting cudraflavanone D as precursor [19].

Compounds 1-5 were tested for their antimalarial, antimicrobial and cytotoxic activities (Table 2). The results showed that compounds 2 and 5 possessed promising antimicrobial activities against $C$. neoformans with $\mathrm{IC}_{50}$ values of $2.95 \mu \mathrm{g} / \mathrm{mL}$ and $1.06 \mu \mathrm{g} / \mathrm{mL}$, respectively. Compound 2 was also active against $P$. aeruginosa, VRE, and MRSA displaying IC50 values of 8.591, 4.316 and $4.47 \mu \mathrm{g} / \mathrm{mL}$, respectively. Compounds 4 and $\mathbf{5}$ exhibited activities against MRSA (IC50 values of 2.07 and $2.60 \mu \mathrm{g} / \mathrm{mL}$, respectively) and S. aureus (2.01 and $2.16 \mu \mathrm{g} / \mathrm{mL}$, respectively). In addition, moderate antimalarial activities for $\mathbf{1}$ and 2 (IC50 $=3.15$ and 4.63 $\mu \mathrm{g} / \mathrm{mL}$ for the D6 clone, and 3.35 and $4.18 \mu \mathrm{g} / \mathrm{mL}$ for the $\mathrm{W} 2$ clone, respectively) were observed. Compounds 1-5 were also screened for their cytotoxic activities against VERO cells, but were found inactive.

\section{Conflict of interest}

Authors declare no conflicts of interest.

\section{Acknowledgements}

This work was supported by National Natural Science Foundation of China (81374062 and 85673179), Hunan Science and Technology Department Funds (2014SK4037 and FJ1007), and United States Department of Agriculture, Discovery \& Development of Natural Products for Pharmaceutical \& Agricultural Applications (58-6060-6-015). 


\section{References}

[1] China National Corp. of Traditional \& Herbal Medicine, Compendium of Chinese medicinal material resources, Beijing: Science Press, 1994.

[2] J.S. Ma, A.R. Brach, Q.R. Liu, A revision of the genus Tripterygium (Celastraceae) , Edinburgh J. Bot. 56 (1999) 33-46.

[3] X.L. Tao, P.E. Lipsky, The Chinese anti-inflammatory and immunosuppressive herbal remedy Tripterygium wilfordii Hook F, Clin. Rheum. Dis. 26 (2000) 29-50.

[4] M. Xue, Z.Z. Jiang, T. Wu, J. Li, L. Zhang, Y Zhao, X.J. Li, L.Y. Zhang, S.Y. Yang, Antiinflammatory effects and hepatotoxicity of Tripterygium-loaded solid lipid nanoparticles on adjuvant-induced arthritis in rats, Phytomedicine 19 (2012) 998-1006.

[5] M. Xue, Z.Z. Jiang, J.P. Liu, L.Y. Zhang, T. Wang, H. Wang, L. Liu, Z.X. Zhou, Comparative study on the anti-inflammatory and immune suppressive effect of Wilforlide A, Fitoterapia 81 (2010) 1109-1112.

[6] A.M. Brinker, J. Ma, P.E. Lipsky, I. Raskin, Medicinal chemistry and pharmacology of genus Tripterygium (Celastraceae), Phytochemistry 68 (2007) 732-766.

[7] C. Wang, C.J. Li, J. Ma, J.Z. Yang, X.G. Chen, Q. Hou, D.M. Zhang, Bioactive sesquiterpene polyol esters from the leaves of Tripterygium wilfordii, Fitoterapia 96 (2014) 103-108.

[8] F. Zeng, W. Wang, Y.S. Wu, M. Dey, M. Ye, M.A. Avery, I.A. Khan, D.A. Guo, Two Prenylated and C-Methylated Flavonoids from Tripterygium wilfordii, Planta Med. 76 (2010) 1596-1599.

[9] M. Jain, S.I. Khan, B.L. Tekwani, M.R. Jacob, S. Singh, P.P. Singh, R. Jain, Synthesis, antimalarial, antileishmanial, and antimicrobial activities of some 8-quinolinamine analogues, Bioorg. Med. Chem. 13 (2005) 4458-4466. 
[10] CLSI, Methods for Dilution Antimicrobial Susceptibility Tests for Bacteria that Grow Aerobically, Approved standard-Fifth Edition, CLSI document M7-A5. Clinical and Laboratory Standards Institute, Wayne, PA, USA, 2000.

[11] CLSI, Susceptibility Testing of Mycobacteria, Nocardia, and Other Aerobic Actinomycetes, Tentative Standard-Second Edition, CLSI document M24-A2. Clinical and Laboratory Standards Institute, Wayne, PA, USA, 2000.

[12] CLSI, Reference Method for Broth Dilution Antifungal Susceptibility Testing of Yeasts Approved Standard-First Edition, CLSI document M27-A1. Clinical and Laboratory Standards Institute, Wayne, PA, USA, 1997.

[13] Y. Zhang, H.Z. Li, Y.J. Zhang, M.R. Jacob, S.I. Khan, X.C. Li, C.R. Yang, Atropurosides A-G, new steroidal saponins from Smilacina atropurpurea, Steroids 71 (2006) 712-719.

[14] D. Slade, D. Ferreira, J.P.J. Marais, Circular dichroism, a powerful tool for the assessment of absolute configuration of flavonoids, Phytochemistry, 66 (2005) 2177-2215.

[15] F.D. Monache, F. Ferrari, M. Pomponi, Flavanones and xanthones from Maclura pomifera, Phytochemistry 23 (1984) 1489-1491.

[16] U. Kokpol, N. Wannachet-isara, S. Tip-pyang, W. Chavasiri, G. Veerachato, J. Simpson, R.T. Weaver, A C-methylflavone from Trianthema portulacastrum, Phytochemistry 44 (1997) 719-722.

[17] S. Sutthivaiyakit, C. Seeka, N. Wetprasit, P. Sutthivaiyakit, C-methylated flavonoids from Pisonia grandis roots, Phytochem. Lett. 6 (2013) 407-411.

[18] C. Wang, C.J. Li, J. Ma, J.Z. Yang, X.G. Chen, Q. Hou, D.M. Zhang, New C-methylated flavonoids and $\alpha$-pyrone derivative from roots of Talinum triangulare growing in Nigeria, Fitoterapia 109 (2016) 169-173. 
[19] L. Chen, Y. Duan, C. Li, Y. Wang, X. Tong, Y. Dai, X. Yao, Four new prenylated flavonoids from the roots of Cudrania tricuspidata, Magn. Reson. Chem. 51 (2013) 842-846. 


\section{Table 1.}

${ }^{1} \mathrm{H}$ NMR ( $500 \mathrm{MHz}$ ) and ${ }^{13} \mathrm{C}$ NMR ( $125 \mathrm{MHz}$ ) spectroscopic data for 1-3.

\begin{tabular}{|c|c|c|c|c|c|c|}
\hline & \multicolumn{2}{|l|}{$\mathbf{1}^{\mathrm{a}}$} & \multicolumn{2}{|l|}{$2^{b}$} & \multicolumn{2}{|l|}{$3^{\mathrm{a}}$} \\
\hline & $\overline{\delta_{\mathrm{H}}}$ & $\delta \mathrm{c}$ & $\overline{\delta_{\mathrm{H}}}$ & $\delta \mathrm{c}$ & $\overline{\delta_{\mathrm{H}}}$ & $\delta \mathrm{c}$ \\
\hline 2 & 5.85 (dd 2.9, 12.9) & 74.7 & 5.61 (dd 3.2, 12.1) & 75.6 & $5.99(\mathrm{dd} 3.8,12.0)$ & 75.3 \\
\hline $3 a$ & $3.13(\mathrm{dd} 17.0,12.9)$ & 43.2 & $2.94(\mathrm{dd} 17.1,12.1)$ & 43.3 & $3.12(\mathrm{~m})$ & 43.3 \\
\hline $3 b$ & $2.98(\mathrm{dd} 17.0,2.9)$ & & 2.77 (dd 17.1, 3.2) & & & \\
\hline 4 & & 197.8 & & 198.7 & & 197.3 \\
\hline $4 a$ & & 103.4 & & 103.4 & & 103.3 \\
\hline 5 & & 160.7 & & 163.2 & & 163.5 \\
\hline 6 & & 105.0 & $5.95(\mathrm{~s})$ & 96.3 & $6.55(\mathrm{~s})$ & 97.0 \\
\hline 7 & & 164.4 & & 166.1 & & 166.9 \\
\hline 8 & & 109.0 & & 109.1 & & 109.1 \\
\hline 8a & & 159.2 & & 162.0 & & 161.4 \\
\hline $1^{\prime}$ & & 120.8 & & 119.3 & & 125.1 \\
\hline $2^{\prime}$ & & 158.1 & & 156.7 & & 155.5 \\
\hline $3^{\prime}$ & $6.64(\mathrm{~s})$ & 100.7 & $6.49(\mathrm{~s})$ & 99.6 & $7.3(\mathrm{~s})$ & 95.6 \\
\hline $4^{\prime}$ & & 155.3 & & 157.0 & & 156.5 \\
\hline $5^{\prime}$ & & 115.0 & & 121.1 & & 121.3 \\
\hline $6^{\prime}$ & $7.50(\mathrm{~s})$ & 125.7 & $7.20(\mathrm{~s})$ & 128.6 & $8.07(\mathrm{~s})$ & 119.7 \\
\hline $1^{\prime \prime}$ & 3.65 (overlap) & 23.3 & $3.21(\mathrm{~m})$ & 22.5 & $3.70(\mathrm{~m})$ & 23.0 \\
\hline $2^{\prime \prime}$ & $5.60(\mathrm{t})$ & 124.6 & $5.19(\mathrm{t})$ & 124.1 & $5.71(\mathrm{t})$ & 124.6 \\
\hline $3 "$ & & 131.3 & & 131.5 & & 131.2 \\
\hline $4 "$ & $1.76(\mathrm{~s})$ & 18.4 & $1.63(\mathrm{~s})$ & 18.0 & $1.80(\mathrm{~s})$ & 18.4 \\
\hline $5 "$ & $1.68(\mathrm{~s})$ & 26.4 & $1.64(\mathrm{~s})$ & 26.1 & $1.71(\mathrm{~s})$ & 26.4 \\
\hline $1^{\prime \prime \prime}$ & 6.49 (d 9.7) & 122.6 & $3.26(\mathrm{~d} 7.1 \mathrm{~Hz})$ & 28.6 & $6.91(\mathrm{~d} 2.1)$ & 107.6 \\
\hline $2^{\prime \prime \prime}$ & 5.58 (d 9.7) & 128.9 & $5.31(\mathrm{t})$ & 124.3 & $7.85(\mathrm{~d} 2.1)$ & 145.7 \\
\hline $3^{\prime \prime \prime}$ & & 77.3 & & 132.8 & & \\
\hline $4^{\prime \prime \prime}$ & $1.46(\mathrm{~s})$ & 28.6 & $1.74(\mathrm{~s})$ & 26.0 & & \\
\hline $5 " '$ & $1.46(\mathrm{~s})$ & 28.6 & $1.71(\mathrm{~s})$ & 17.9 & & \\
\hline $\mathrm{CH}_{3} \mathrm{O}$ & $3.71(\mathrm{~s})$ & 56.1 & $3.82(\mathrm{~s})$ & 56.0 & $3.76(\mathrm{~s})$ & 56.4 \\
\hline $\mathrm{CH}_{3}-$ & $2.45(\mathrm{~s})$ & 9.1 & & & & \\
\hline OH-5 & $13.10(\mathrm{~s})$ & & & & $12.86(\mathrm{~s})$ & \\
\hline
\end{tabular}

${ }^{a}$ NMR spectral data of $\mathbf{1}$ and $\mathbf{3}$ in Pyridine- $d_{5}$.

${ }^{\mathrm{b}} \mathrm{NMR}$ spectral data of $\mathbf{2}$ in $\mathrm{CD}_{3} \mathrm{OD}$. 
Table 2.

Anti-infective Activities and Cytotoxicity of Compound 1-5.

\begin{tabular}{|c|c|c|c|c|c|c|c|c|}
\hline \multirow{2}{*}{ Compounds } & \multicolumn{2}{|c|}{ Antimalarial $^{a}$} & \multicolumn{5}{|c|}{ Antimicrobial $^{b}$} & \multirow{2}{*}{$\begin{array}{c}\text { Cytotoxicity }^{c} \\
\text { Vero }\left(\mathrm{IC}_{50}\right)\end{array}$} \\
\hline & $\begin{array}{c}\text { P. falciparum } \\
\text { D6 (IC50) }\end{array}$ & $\begin{array}{c}\text { P. falciparum } \\
\text { W2 (IC50) }\end{array}$ & $\begin{array}{c}\text { C. neoformans } \\
\text { (IC50) }\end{array}$ & $\begin{array}{c}\text { P. aeruginosa } \\
\text { (IC50) }\end{array}$ & $\begin{array}{l}\text { VRE } \\
\left(\mathrm{IC}_{50}\right)\end{array}$ & $\begin{array}{l}\text { MRS } \\
\left(\mathrm{IC}_{50}\right)\end{array}$ & $\begin{array}{l}\text { S. aureus } \\
\text { (IC50) }\end{array}$ & \\
\hline 1 & 3.15 & 3.35 & na & na & na & na & nt & nc \\
\hline 2 & 4.63 & 4.18 & 2.95 & 8.59 & 4.32 & 4.47 & nt & nc \\
\hline 3 & na & na & na & na & na & na & $\mathrm{nt}$ & nc \\
\hline 4 & nt & nt & na & nt & $\mathrm{nt}$ & 2.07 & 2.60 & nc \\
\hline 5 & nt & nt & 1.06 & nt & $\mathrm{nt}$ & 2.01 & 2.16 & nc \\
\hline Artemisinin & 0.0085 & 0.0090 & $\mathrm{nt}$ & nt & nt & $\mathrm{nt}$ & nt & nt \\
\hline Amphotericicin B & $\mathrm{nt}$ & $\mathrm{nt}$ & 0.75 & nt & $\mathrm{nt}$ & nt & $\mathrm{nt}$ & $\mathrm{nt}$ \\
\hline Ciprofloxacin & $\mathrm{nt}$ & $\mathrm{nt}$ & $\mathrm{nt}$ & 0.06 & $\mathrm{nt}$ & 0.15 & 0.10 & nt \\
\hline Vancomycin & nt & nt & nt & $\mathrm{nt}$ & 3.3 & nt & nt & nt \\
\hline
\end{tabular}

${ }^{a}$ highest test concentration at $4.76 \mu \mathrm{g} / \mathrm{mL}$.

${ }^{b}$ highest test concentration at $20 \mu \mathrm{g} / \mathrm{mL}$.

${ }^{c}$ highest test concentrations at $4.76 \mu \mathrm{g} / \mathrm{mL}$. na, not active. nt, not tested. nc, not cytotoxic.

$\mathrm{IC}_{50}$ is the concentration $(\mu \mathrm{g} / \mathrm{mL})$ that affords $50 \%$ inhibition of growth.

Both antiinfective activities and cytotoxicity are expressed as mean values of three experimental data. 


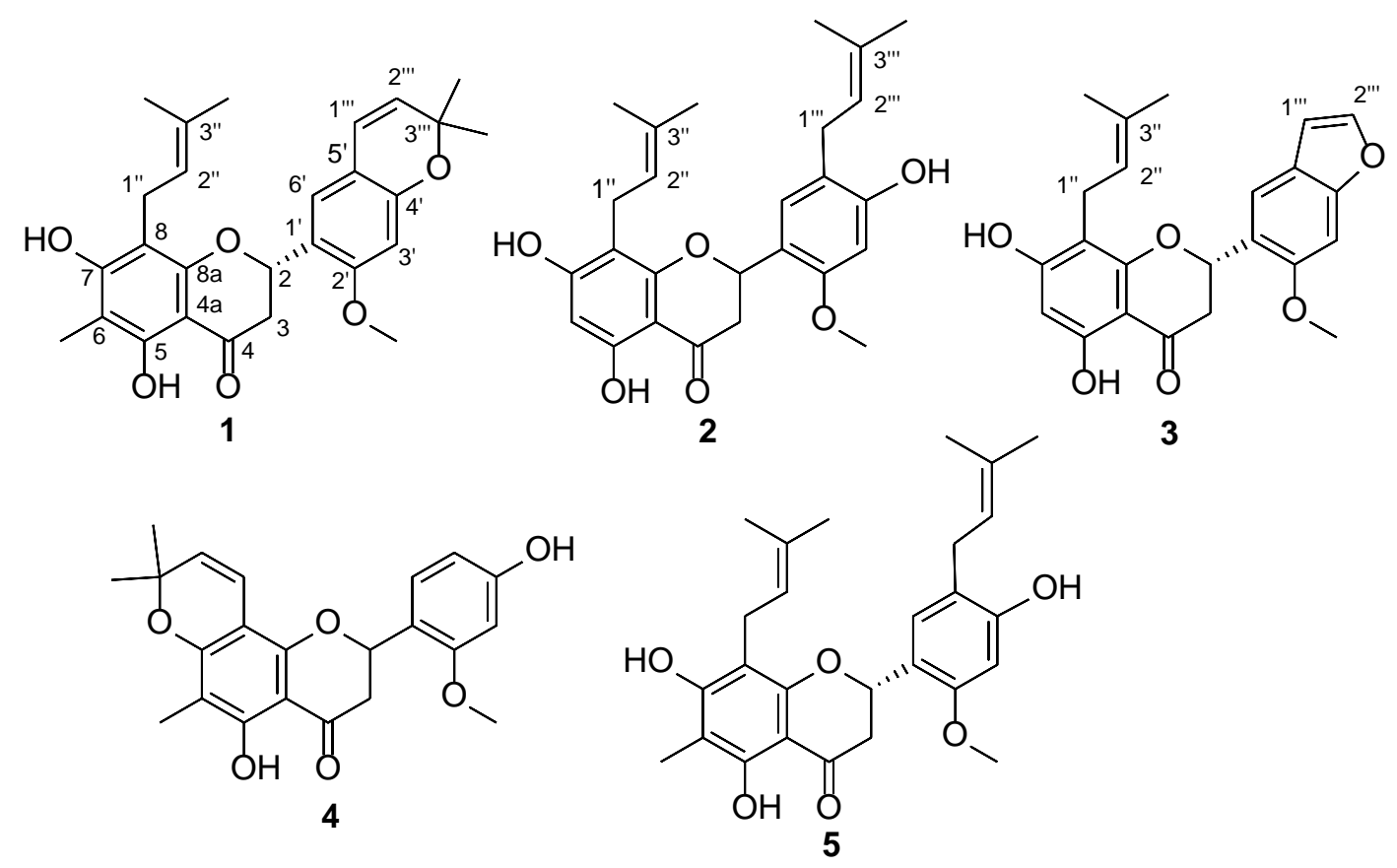

Fig. 1. Structures of 1-5. 


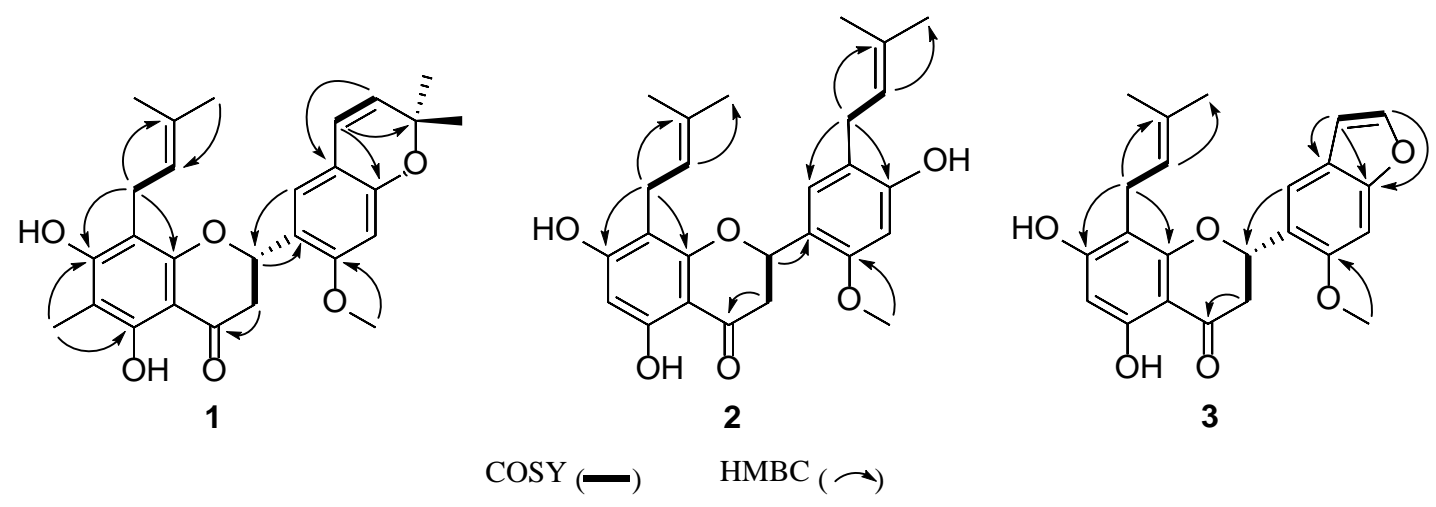

Fig. 2. Key HMBC and ${ }^{1} \mathrm{H}-{ }^{1} \mathrm{H}$ COSY correlations in 1-3. 